IZA DP No. 5256

What Do Unions Do to Pension Performance?

William E. Even

David A. Macpherson

October 2010 


\title{
What Do Unions Do to Pension Performance?
}

\author{
William E. Even \\ Miami University \\ and IZA
}

\author{
David A. Macpherson \\ Trinity University \\ and IZA
}

\section{Discussion Paper No. 5256 \\ October 2010}

\author{
IZA \\ P.O. Box 7240 \\ 53072 Bonn \\ Germany \\ Phone: +49-228-3894-0 \\ Fax: +49-228-3894-180 \\ E-mail: iza@iza.org
}

\begin{abstract}
Any opinions expressed here are those of the author(s) and not those of IZA. Research published in this series may include views on policy, but the institute itself takes no institutional policy positions.

The Institute for the Study of Labor (IZA) in Bonn is a local and virtual international research center and a place of communication between science, politics and business. IZA is an independent nonprofit organization supported by Deutsche Post Foundation. The center is associated with the University of Bonn and offers a stimulating research environment through its international network, workshops and conferences, data service, project support, research visits and doctoral program. IZA engages in (i) original and internationally competitive research in all fields of labor economics, (ii) development of policy concepts, and (iii) dissemination of research results and concepts to the interested public.
\end{abstract}

IZA Discussion Papers often represent preliminary work and are circulated to encourage discussion. Citation of such a paper should account for its provisional character. A revised version may be available directly from the author. 
IZA Discussion Paper No. 5256

October 2010

\section{ABSTRACT}

\section{What Do Unions Do to Pension Performance?*}

This study argues that the promotion of union goals could have positive, negative, or neutral effects on risk adjusted return performance. Moreover, the union's ability and incentive to use pension assets to promote union goals will vary with the design of the pension. Using panel data on over 36,000 pension plans drawn from IRS Form 5500 filings, we empirically estimate the effects of unions on risk adjusted returns and find that the union effect on performance varies in ways that are consistent with our priors. In particular, unions have the largest negative effect among multi-employer defined contribution plans and the negative effect of unions can be eliminated by a switch to participant direction. Also, we find that unions improve performance for single employer defined contribution plans.

JEL Classification: J32, J51

Keywords: $\quad$ unions, rate of return, pension, defined benefit, defined contribution

Corresponding author:

David A. Macpherson

Department of Economics

Trinity University

San Antonio, TX 78212

USA

E-mail: David.Macpherson@trinity.edu

\footnotetext{
" We thank Stuart Dorsey, Darren Grant, Barry Hirsch, and John Turner for providing helpful comments on an earlier draft.
} 


\section{Introduction.}

For decades, unions have attempted to leverage pension assets to promote union interests. For example, in 1980 the AFL-CIO encouraged unions to direct pension investments toward communities where union workers live, firms with good labor relations, and firms with largely domestic work forces (Bennett and Johnson, 1981). More recently, the AFL-CIO issued proxy voting guidelines for trustees of union pension plans (AFL-CIO, 2003).

Opponents of union pension activism argue that it violates the Employee Retirement and Income Security Act of 1974 (ERISA) requirement that plan fiduciaries use pension assets for the exclusive purpose of providing benefits to participants. According to this point of view, union pension activism hurts participants by reducing the risk-adjusted return on assets. ${ }^{1}$ However, the Department of Labor has ruled on several occasions that pension fiduciaries may consider collateral benefits in choosing between benefits, so long as there is no sacrifice to risk-adjusted returns. Consequently, much of the debate over union activism with pension funds is over the question of how union activities affect risk adjusted returns

This study provides empirical evidence on how unions affect pension performance. As background to our empirical work, we first review the controversy over whether ERISA restricts various types of union pension activism. We also discuss how the union's ability to implement activist policies will vary depending on whether the pension is a single- or multi-employer plan; a defined benefit or defined contribution plan; or a trustee- or participant-directed plan. Our empirical analysis of IRS Form 5500 filings over the past two decades illustrates that union effects on pension performance vary significantly with pension structure. Moreover, our evidence suggests that the

\footnotetext{
${ }^{1}$ See, for example, Vernuccio (2009) or Entine (2008).
} 
recent shift from defined benefit (DB) to defined contribution (DC) plans and the growth of participant direction among DC plans dampens any negative effects of unions on risk-adjusted returns.

\section{Background.}

Unions have a long history of promoting the use of pension assets to advance union goals. This "pension activism” includes a diverse group of activities ranging from investing assets in unionized companies, to making loans to support projects that favor union labor, to proxy voting that support union objectives. However, there has been considerable controversy regarding the legality of such activities. In particular, ERISA requires that pension fiduciaries manage a plan for "the exclusive purpose of providing benefits to participants” (Section 404(1)(a)). Some argue that this language prevents unions from using pension assets to advance their goals. However, in 1998, the Department of Labor provided an advisory opinion indicating that the fiduciary standards of ERISA do not preclude consideration of collateral benefits so long as "the investment offering the collateral benefits is expected to provide an investment return commensurate to alternative investments having similar risks". 2 This interpretation makes it clear that union pension activism is acceptable so long as there is no reduction in the risk-adjusted return of the pension portfolio. Disagreement remains, however, about the impact of union pension activism on risk-adjusted returns. Undoubtedly the answer to this question depends upon the particular manner in which the union attempts to advance its goals.

One of the most common ways that unions promote their goals with pension funds is by investing in companies that employ union labor. This can be accomplished by direct purchases of the

\footnotetext{
${ }^{2}$ Advisory opinion 98-04A issued by the Pension and Welfare Benefits Administration can be found at http://www.erisaadvisoryopinions.com .
} 
company’s stock, but more recently, registered investment companies, insurance companies and banks are designing investments that are diversified across a wide spectrum of union employers so as to offer greater risk diversification. For example, the Housing Investment Trust (HIT) and the Building Investment Trust (BIT) are bank-managed trusts that serve union pension plans. These trusts invest entirely in residential or commercial projects that employ union labor. ${ }^{3}$ Another example is the IAM fund managed by State Street Group that invests the majority of its assets in equity securities of companies that employ members of the International Association of Machinists and Aerospace workers. Some banks attract union pension funds by offering "target CDs” that provide a guaranteed rate of return but the bank agrees to make loans to finance projects that employ union labor. ${ }^{4}$ One such agreement includes the purchase of a CD by a Roofers union pension fund with the agreement that low interest loans be provided for roofing projects performed by an approved union contractor.

Calabrese (1999) reports that over 80 percent of targeted investments by union pension funds in the 1990s were dedicated to financing union-built construction, though there is some evidence of increased use of private debt and equity purchases to promote union goals. For example, the Union Labor Life Insurance Company (ULLICO) established a private equity fund that invests in small startup firms in exchange for an agreement that the firm confer collateral benefits to the union - such as union neutrality or card check recognition.

Another way that unions can use pension assets to promote their own goals is through shareholder activism. Prevost et al. (2009) points out that union sponsored pension funds submitted 43 percent of shareholder corporate governance proposals in 2004. Union proposals vary in their objectives. Some restrict executive compensation, others place restrictions on takeover defenses,

\footnotetext{
${ }^{3}$ For details on asset holdings and objectives, see www.aflcio.hit.com and www.aflcio.bit.com.

${ }^{4}$ Calabrese (1999) provides specific examples of such agreements.
} 
while others require that union representatives be included on corporate boards or that managerial pay be tied to employee welfare.

Unions have also increased pressure on mutual funds to vote proxies in accordance with union objectives. Partly in response to union pressures, the Securities and Exchange Committee mandated disclosure of mutual fund proxy voting since 2003. In the same year, the AFL-CIO issued proxy voting guidelines for its union membership and began rating mutual funds on the basis of their proxy voting behavior (Cremers and Romano, 2007). Such ratings were designed to use union pension assets to influence mutual fund voting behavior. As an example, the AFL-CIO wrote several investment firms in 2005 and suggested that organized labor would consider a firm’s position on Social Security privatization (Furchtgott-Roth, 2008).

While it is clear that unions have found numerous ways to use pension funds to promote union goals, the effect on risk-adjusted performance will depend upon the specifics. Consider, for example, a policy that tilts investments toward the stock of companies that employ union labor. Initially, one might think that such a policy would reduce pension performance if unions reduce firm profitability though there is conflicting evidence on that point. ${ }^{5}$ In theory, unions can increase or decrease profits depending on whether any increase in labor costs associated with unionization exceed any positive effects on productivity. A recent study by Lee and Mas (2009) finds that a union election victory results in about a 10 percent decline in the firm's stock value. However, they also note that if financial markets are efficient, this decline in stock price should reflect the expected effect of the union on the present value of all future profits. This implies that if financial markets are efficient and the union status of companies is public information, the risk-adjusted return on stock in union and nonunion companies should be identical. On the other hand, if unions use pension assets to fund loans to

\footnotetext{
${ }^{5}$ Hirsch (2007) reviews the conflicting evidence on how unions affect firm profitability and discusses how omitted variables problems and the potential endogeneity of unionization efforts to firm profitability make it difficult to properly estimate the effect of unions on firm profitability.
} 
projects that will employ union labor at below market rates, the efficient markets theory is irrelevant. In this case, the pension is clearly sacrificing risk-adjusted returns to promote collateral benefits for union members.

Shareholder activism is another way that unions can use pension assets to promote union goals. The effect of such activities on risk-adjusted performance depends on the specific governance changes that the union proposes. For example, if the union promotes changes in corporate governance leading to increased union bargaining power and thus damages corporate profits, there will be a reduction in risk-adjusted performance of the stock as the price falls to reflect a lower expected stream of future profits. If the change in corporate governance improves corporate performance (e.g., by improving corporate board structure or executive compensation rules), risk-adjusted performance would be enhanced.

Renneboog and Szilagyi (2009) and Prevost et al. (2008) show both positive and negative stock price reactions to union sponsored proposals for changes in corporate governance. Whether a proposal has a positive or negative effect depends on the nature of the proposal as well as the governance structure of the firm that is targeted. Agrawal (2008) finds that union voting behavior on corporate governance proposals varies depending on whether the targeted company employs union workers. This suggests that union votes on governance proposals are driven partly by the anticipated effect on union employees. For example, corporate governance proposals eliminating “poison pills” would make hostile takeovers easier and may improve stock performance. However, a hostile takeover could also result in layoffs for existing workers. Consequently, the union might favor elimination of poison pills when the firm has a nonunion workforce, but oppose elimination if it increases the risk of layoffs for union employees. 
Unions can also influence pension fund performance by potentially improving monitoring pension fund managers. Without the union, it may not be cost effective for any single worker to spend the time and effort necessary to monitor the fund manager. With a union, pension participants are able to act collectively, reduce the free rider problem with monitoring, and improve monitoring of the pension fund manager. ${ }^{6}$

The Importance of Plan Design.

While the union has a variety of ways to leverage pension assets to promote union goals, there are several pension design features that can affect either the union's ability or incentive to pursue activist policies. These design features include: (1) whether the pension is a single or multi-employer plan; (2) whether the plan is a DB or DC plan; and (3) whether the plan is trustee- or participant directed.

In collectively bargained single-employer plans, the firm chooses the pension manager and the union is not guaranteed any control over the pension assets. While the union has no direct control over pension management, it can use the collective bargaining process to pressure the firm to promote union goals with the pension assets.

Unions have the greatest control over investments in multi-employer (also called TaftHartley) pension plans where the plan covers workers from a variety of employers. Such plans are most common where workers are not attached to a particular firm - for example, in the construction

\footnotetext{
${ }^{6}$ This argument is similar to that made by others that institutional ownership of a corporation improves monitoring because large equity positions make research and monitoring expenditures more cost effective. Thus, for example, corporations with many small owners may be monitored less closely than those with a few large institutional owners. See, for example, Agrawal and Mandelker (1990) or Shleifer and Vishny (1986).
} 
and trucking industries. The Taft-Hartley Act requires that such plans be jointly administered by union and employer representatives.

Consistent with the premise that unions have little influence in single employer plans, Dorsey and Turner (1990) found that collective bargaining had no impact on the performance of singleemployer plans, but had negative effects in multi-employer plans. However, they also found that the inferior performance of the multi-employer plan that existed in the late 1970s disappeared during the 1980s. They suggest that the shortfall in performance was eliminated when the Department of Labor issued advisories in 1980-81 warning that an explicit sacrifice of earnings for nontraditional objectives was a violation of ERISA fiduciary requirements. ${ }^{7}$

Whether the pension is a DB or DC plan could alter the union's incentive to sacrifice returns for collateral union benefits. If the firm has a DB plan, the employer is liable for employee benefits and any shortfall in returns are at the expense of the employer. Consequently, with a DB plan, employers will be reluctant to sacrifice returns to accommodate union investment preferences that sacrifice returns unless the union is willing to provide some other concession in the bargaining process to offset this loss. On the other hand, if the firm has a DC plan, the employer is liable only for contributions to the pension, and any shortfall in returns reduces the employee's account balance at retirement. Consequently, a switch from DB to DC plans could make employers more complacent and make it less likely that they object to union activities that reduce returns. On the other hand, the DC plan could make union membership less willing to allow investment activities that damage returns since it comes at their expense. However, to the extent that the union leadership is able to convince

\footnotetext{
${ }^{7}$ An alternative explanation for the underperformance of union pension funds is that union plans tilt equity investments toward unionized companies and the stock returns were lower for unionized companies in the late 1970s and early 1980s, but were similar for union and nonunion firms both before and after these time periods (Hirsch and Morgan 1994).
} 
their members that "pro-union” investment policies are, on net, beneficial to the workers, the shift to a DC plan could increase pro-union policies that might reduce pension performance.

Whether a DC plan is trustee- or participant-directed can also affect the extent to which union pension funds sacrifice returns to promote union goals. In a trustee-directed DC plan, each participant receives shares of a common portfolio in proportion to his or her contributions and investment earnings. In participant-directed plans, the pension sponsor chooses the list of investment vehicles offered by the plan, but each individual decides how much to invest in the various investment options. Among DC plans, there has been a pronounced shift from trustee- to participant-directed plans over the past 20 years. $^{8}$

A switch from trustee to participant direction could reduce union pension activism if it reduces risk-adjusted returns by tilting investments toward union projects. The rationale for this effect rests on two assumptions: (1) investment decisions are made collectively in trustee directed plans, but individually in participant directed plans; and (2) the collateral benefits of an investment are distributed equally across all members, regardless of which members invested their own funds in the project.

To illustrate the effect of a switch to participant direction, suppose that $\mathrm{N}$ members are each deciding whether to invest a fixed amount $C$ to one of two investment options for a single year. The “passive” investment pays a competitive risk-adjusted rate of return but generates no collateral benefits for the union members. For each dollar diverted to the “union” investment, the risk adjusted rate of return is reduced by $\mathrm{p}$, the group of union members who participate in the pension plan receive $\mathrm{b}$ in collateral benefits, but these benefits are equally distributed across members so each receives benefits of $\mathrm{b} / \mathrm{N}$.

\footnotetext{
${ }^{8}$ Even and Macpherson (2010) report that, between 1988 and 2005, the percentage of defined contribution participants who manage some or all of their pension assets increased from 15 to 86 percent.
} 
In the case of the trustee directed plan, the decision to invest in the union project should be based upon whether the benefits to the group exceed the costs to group. As a consequence, the union investment is chosen if $b^{*} C^{*} N>p^{*} C^{*} N$ (i.e., $b>p$ ). In the case of the participant directed plan, each worker is allowed to decide whether to invest his or her funds in the union project. The benefit to a worker of investing her funds in the activist project is $b^{*} \mathrm{C} / \mathrm{N}$ and most of the collateral benefits spill over to other members. Since the loss in returns for the individual participant is $\mathrm{p}^{*} \mathrm{C}$, the individual will invest in the activist project only if $\mathrm{b} / \mathrm{N}>\mathrm{p}$. The net result is that a switch from trustee to participant direction reduces the chance that the union investment is pursued because individual decision causes workers to ignore (or at least discount) the spill-over benefits for other members. ${ }^{9}$ With trustee direction, the individual members know that if the union investment is approved, all members contribute to the union investment and they will reap the spill-over benefits from other members’ investments.

In review, union pension activism could have positive, negative, or zero effects on risk-adjusted returns. Targeting investments that generate collateral benefits for union members could reduce riskadjusted returns, but it could have zero effect if the investments are made in a competitive and efficient asset market. Shareholder activism by unions could have either positive or negative effects on performance depending on the nature of the governance proposals. The union could also improve monitoring of pension fund managers by reducing inherent free rider problems.

The union influence over pension investment practices will differ depending on the specifics of the plan type. Unions will have greater influence in multi-employer plans since they are directly involved in management of the pension. Unions may have greater influence in DC than DB plans

\footnotetext{
${ }^{9}$ While a switch to participant direction could reduce investments in union projects when risk-adjusted returns are reduced, this same logic does not apply to shareholder activism since passage of proxy votes requires collective action - regardless of whether the plan is participant directed. Consequently, individual participants will consider spillover benefits to all members when deciding whether to support proxy votes.
} 
since the DC plan shifts the cost of any underperformance to the union and should make the employer less resistant to union influence. When a DC plan is participant directed, the union membership will act more in their individual interest (instead of the union's interest) when deciding whether to invest in pro-union project that could reduce risk-adjusted returns.

\section{Data and Empirical Methodology.}

To investigate the effect of unions on pension fund performance, we draw data from pension plan filings of IRS Form 5500 for private sector plans between 1988 and 2007. This data contains information on asset values, investment income, administrative and asset management expenses that can be used to estimate an annual rate of return. Because plans with less than 100 participants fill out an abbreviated form and are not included in the public release database annually, we restrict our analysis to plans with 100 or more participants and exclude any plan-year observations with missing data on union status. We also exclude Employee Stock Ownership plans because they are uncommon in collectively bargained environments, not designed to be well-diversified portfolios, and present special issues when calculating the rate of return. ${ }^{10}$ This results in a sample of 149,118 pension plans with a total of 1,010,418 plan year observations. For the plans filing in 2007, our sample includes 64,138 plans with $\$ 4.2$ trillion of assets and 57.4 million active pension participants. Because our sample excludes small plans (as well as ESOPs and plans with missing data), our 2007 sample covers only 9 percent of all private sector pension plans, but 70 percent of the active participants and 68 percent of the assets.

To estimate the rate of return on pension plans in the Form 5500 data, we use the approach described in McCarthy and Turner (1989). The rate of return is calculated as investment income

\footnotetext{
${ }^{10}$ See Conte (1994) for a discussion of the issues with calculating the rate of return on ESOP plans.
} 
(dividends, interest, and both realized and unrealized capital gains) divided by assets at the beginning of the year. ${ }^{11}$ The rate of return estimates are net of any expenses charged to any externally managed accounts (e.g., master trusts, registered investment companies, or investments with insurance companies) and also subtract any administrative or asset management expenses explicitly charged to the pension plan. The Form 5500 data may understate administrative expenses because an employer might absorb some of these expenses and fail to report them on the Form $5500 .{ }^{12}$

Figure 1 compares the annual rate of return (net of expenses) on union and nonunion plans between 1988 and 2007. The value weighted return on all NYSE, AMEX and NASDAQ stocks is presented as a benchmark. ${ }^{13}$ The average annual returns on union and nonunion plans track each other closely. Average pension returns are highly correlated with stock market returns, but there is less volatility in pension returns. This is to be expected since most pension funds have a significant share of assets in bonds. For example, in 2009, 39\% of assets in pensions sponsored by the S\&P 1500 firms were in bonds (Hartsohn, 2010).

To examine risk-adjusted rate of return performance (net of expenses), we restrict the sample to plans with at least 10 years of data on returns, assets, pension type, investment income, and

\footnotetext{
${ }^{11}$ To be precise, the annual rate of return is calculated as net income from assets divided by invested assets. The net income from invested assets is defined as the sum of interest, dividends, rents, royalties, net realized gain or loss on sale or exchange of assets, other income, unrealized appreciation or depreciation of assets, and net investment gain from trusts minus unrealized appreciation or depreciation of buildings and depreciable property used in plan operations. Investible assets are defined to reflect assets at the beginning of the year plus additional purchases of assets through the year with the assumption that all purchases are made midyear.

${ }^{12}$ Both Mitchell and Andrews (1981) and Dorsey and Turner (1990) note that administrative expenses are rarely reported in single employer plans because the firm frequently absorbs the costs as part of their everyday operations. However, when pension funds are externally managed (e.g., registered investment companies, insurance companies, or master trusts) there are typically explicit charges for administration of the plan and investment management fees are typically subtracted from the returns on the underlying mutual funds that they manage.

${ }^{13}$ The returns on the overall market are drawn from Kenneth French's website at http://mba.tuck.dartmouth.edu/pages/faculty/ken.french/Data Library/f-f factors.html . The sample used to generate the plot of annual returns is restricted to the $81 \%$ of pension plans whose filing year matches the calendar year. There are relatively few observations in most of the other months which reduces the precision of the estimated mean for those months.
} 
participant directed status. This reduces the sample to 36,012 plans and 488,370 plan year

observations.

One concern with our panel data set is that it could create a survivor bias in estimated rates of return. Ex ante, we have no strong priors on the direction of any survivorship bias since plans could have fewer than 10 years of data for a number of reasons that could be uncorrelated with pension performance. For example, plans that started in 1999 or later would all be excluded since it would be impossible for them to generate 10 years of data by the end of our sampling period (2007). Also, plans that existed prior to 1999 could have been terminated if there was a merger of firms, if one plan was shut down and replaced by another (e.g. a DB is replaced by a DC), or if the sponsoring firm went bankrupt. ${ }^{14}$

To determine whether survivor bias is a problem, we estimate a regression of net pension returns as a function of whether it survives the requirement for 10 years of data, controlling for plan characteristics and fixed year effects. The results indicate that the difference between the average net return in the survivor sample and full sample (the "survivor bias") is +7 basis points for nonunion plans, +10 basis points for single employer union plans, and +12 basis points for multi-employer union plans. ${ }^{15}$ Consequently, controlling for plan characteristics and year effects, the effect of restricting the sample to plans with 10 or more years of data results in slightly higher returns for all three plan types, but the effect on differential performance across plan types is negligible. ${ }^{16}$

\footnotetext{
${ }^{14}$ If pensions hold some share of assets as company stock, bankruptcy or mergers could be related to pension performance. However, our elimination of ESOP plans reduces this potential source of survivor bias.

${ }^{15}$ In an OLS regression of returns on a survivor dummy and other controls using all plans (survivors and non-survivors), the regression line passes through the mean so that $\bar{F}=\hat{a}_{0}+\hat{a}_{1} \bar{s}+\bar{X} \bar{\beta}$ where $\bar{x}$ is the mean return for all plans, $\bar{s}$ is the mean of a dummy variable indicating whether a plan is a survivor, and $\bar{Z}$ is a vector containing the means of the plan characteristics and year effects. Controlling for plan characteristics and year effects, the difference between the mean return of a sample with only survivors $(\bar{s}=1)$ and the entire sample is $1-\alpha_{1} \bar{s}$. This logic is applied separately for each type of plan by introducing interaction terms between dummies for plan type (non-union, union single employer, union multi-employer) and the survivor dummy.

${ }^{16}$ The comparison of survivor and non-survivors is conditioned on the plan characteristics and controls for year effects. Without controlling for these differences in plan characteristics, the survivor bias appears larger since, for example, the
} 
Table 1 provides the sample characteristics for the union and nonunion pension plans in our panel data set. Over the sample period, union pension plans earn a slightly higher rate of return than nonunion plans, but some of this is offset by higher administrative expenses. Union plans also have a slightly lower standard deviation of returns within plans (8.30 versus 9.83). While these simple statistics might lead one to conclude that unions improve returns and lower risk, they fail to account for the fact that union and nonunion plans differ in several ways that contribute to performance differentials.

Some of these differences are made apparent in the comparison of sample means. First, the average union plan has nearly three times as many participants. Since there are scale economies in pension administration with respect to both the number of participants and assets per participant, this should ceteris paribus, result in superior performance among union plans. ${ }^{17}$ Second, economies of scope in the administration of pension plans should give union plans an advantage because union employers are more likely to offer more than one pension plan. ${ }^{18}$ Third, union plans are three times more likely than nonunion plans to be a DB plan (69.1\% vs. 22.9\%). Since DB plans are more expensive to administer than DC plans, this will reduce the average performance of union plans relative to non-union plans. ${ }^{19}$ Union plans are also less likely to be participant directed, have a 401(k), profit sharing, or money purchase feature. To the extent that such features impact the administrative costs of the plan, this could result in differential performance by union status.

survivors tend to be larger and older plans that have performance advantages for reasons we discuss below. Also, since any plan started after 1998 is excluded from the survivor group, the survivor group includes fewer observations from this time period which had below average returns (see figure 1 ).

${ }^{17}$ Investment Company Institute (2009) provides a good review of the factors affecting administrative costs and shows economics of scale in admininstration with respect to balance per participant and number of participants.

${ }_{18}$ The fact that an employer offers more than one pension plan does not necessarily mean that the same workers are covered by multiple plans. That is, for example, a given employer may offer two pension plans and these two plans may cover the same workers or two entirely different groups of workers. Regardless of whether the plans cover the same workers or different workers, there is the potential to take advantage of economies of scope in administration.

${ }^{19}$ Hustead (1998) shows that administrative expenses are higher in DB than in DC plans. He also provides evidence that regulatory reforms have driven up the cost of DB relative to DC plans over time and may partially account for the shift from DB to DC plans, particularly at small firms. 
To determine how unionism affects risk-adjusted return performance, we use the Fama-French (FF) five factor model (Fama and French, 1993). This methodology is a common way to examine the risk and return features of a stock or mutual fund. ${ }^{20}$ The essence of the approach is described by the regression below where excess pension returns are regressed on a constant and five FF factors:

$$
\text { (1) } r_{i \varepsilon}=\alpha_{i}+\beta_{1 i} V W R F_{\varepsilon}+\beta_{2 i} S M B_{\varepsilon}+\beta_{3 i} H M L_{\varepsilon}+\beta_{4 i} D E F_{\varepsilon}+\beta_{3 i} T e r m_{z}+e_{i \varepsilon}
$$

where $\mathrm{i}$ indexes the pension plan and $\mathrm{t}$ indexes time. The dependent variable is the annual return on the pension portfolio (net of expenses) in excess of the average of the corresponding annualized onemonth U.S. Treasury bill rates. The control variables include five FF factors. The first three represent stock market risk factors: VWRF is the excess return on the overall stock market (relative to the annualized yield on one-month U.S. Treasury bills) as measured by the value-weighted returns on all stocks traded on the NYSE, AMEX, and NASDAQ; SMB (small minus big) is the difference in returns on small- versus large-cap portfolios; and HML (high minus low) is the difference in returns on value and growth portfolios. $^{21}$ The remaining two factors represent bond risk. TERM is the difference in annual returns on 20 year government bonds and one month treasury bills. DEF is the difference between the annual returns on 20 year government bonds and a portfolio of 20 year AAA and AA corporate bonds. ${ }^{22}$

\footnotetext{
${ }^{20}$ For recent examples employing this methodology to mutual and pension funds, see Tonks (2005) and Cohen et al. (2008).

${ }^{21}$ The construction of these variables and the data are available from Kenneth French's website at http://mba.tuck.dartmouth.edu/pages/faculty/ken.french/Data_Library/f-f_factors.html .

${ }^{22}$ The data source for all bond returns is Morningstar (2009). Because the pension plan reporting year does not necessarily coincide with the calendar year, we annualize monthly values for the risk factors and merge them to each pension plan based upon the 12 month period corresponding to the plan's Form 5500 filing.
} 
In the FF model, the $\beta$ s reflect the exposure to risk factors in the market. For example, if a pension is entirely invested in the overall market portfolio (as measured by VWRF), $\beta_{1}$ would equal one; and $\beta_{2}$ through $\beta_{5}$ would equal zero. If instead the portfolio was invested entirely in one month U.S. Treasury bills, $\beta_{1}$ through $\beta_{5}$ would equal zero. If there were no administrative, record keeping, or investment fees for managing the pension, $\alpha$ would equal zero in both cases. To the extent that there are such fees, $\alpha$ will be negative. Idiosyncratic risk is captured in the residual. In theory, idiosyncratic risk is not rewarded with higher expected returns. ${ }^{23}$

The FF regression is estimated separately for each pension plan and by union status using OLS. Because there are relatively few observations per plan (minimum of 10, maximum of 20), the coefficient estimates may be estimated imprecisely making it difficult to accurately test for differences in plan behavior by union status. The large number of plans, however, potentially mitigates this problem and as seen below, the vast majority of FF regressions have statistically significant explanatory power and we are able to find statistically significant differences in the parameters by union status.

The estimated FF coefficients are used in a second stage analysis to examine the impact of participant direction on pension performance. First, using a procedure similar to Carhart (1997) for analyzing mutual fund performance, the effect of unionism on risk-adjusted performance is estimated by regressing each plan's measure of risk adjusted performance including the year-specific residual from the FF equation $\left(a_{i}+e_{i z}\right)$ on a dummy variable indicating whether the plan is collectively bargained. Notice that this measure of performance varies across time for a given plan because the residual from the first stage equation is added to $\alpha_{\mathrm{i}}$. This allows us to estimate whether control

\footnotetext{
${ }^{23}$ This approach to measuring risk-adjusted performance is very similar to that used by Dorsey and Turner (1990) for examining pension performance except that we use multiple risk factors reflecting different types of stock and bond market risk whereas they use a single factor based on a mixed stock and bond market index.
} 
variables that vary over time for a given plan (or across plans) are systematically related to pension performance. Also, the second stage regression corrects for clustering of residuals by plan and heteroskedastic errors. Because union status might be correlated with other variables that impact performance, we incrementally add controls for other pension characteristics that might affect performance. In addition to the controls for plan characteristics, we include year dummies that might account for changes in performance due to regulatory or technological changes that might affect administrative or asset management expenses.

\section{Results}

First-Stage Regression Results.

In the first-stage, a separate FF regression is estimated for each of the 36,012 pension plans in the panel data set. The means of the estimated coefficients are presented in table 2 along with the percentage of times that each coefficient is statistically different from zero at the .05 level. $^{24}$ The number of regressions corresponds to the number of pension plans in the panel data set $(36,012)$. The average of the regression R-squared values is .84 and the FF factors have statistically significant explanatory power for excess returns in the vast majority of pension plans. For example, the excess return on the market equity index has an average coefficient of .49 and is statistically different from zero at the .05 level for over 98 percent of pension plans. This is consistent with figure 1 which shows that the return on the average pension plan tracks the market index but is less volatile. The other FF factors have smaller coefficients (in absolute value) and are statistically significant less

\footnotetext{
${ }^{24}$ The t-statistics used to determine statistical significance for a given plan's regression coefficients are compared to criticial values from the t-distribution with (n-6) degrees of freedom where $n$ represents the number of observations for that plan.
} 
frequently, but 4 of the $5 \mathrm{FF}$ factors are statistically different from zero (at the .05 level) for more than three quarters of the pension plans. Overall, despite the relatively small sample sizes for each pension plan, the FF regressions generally have statistically significant explanatory power.

The results of the first-stage regressions suggest that union plans have slightly lower risk adjusted performance (21 basis points) than nonunion plans. Also, unionized plans have less exposure to stock market risk. For the average plan, a 10 percentage point increase in the excess return on the market portfolio increases pension returns by 5.1 percentage points for non-union plans and by 4.2 percentage points for union plans.

Figure 2 provides a histogram of the estimates of risk-adjusted performance by union status and shows that the lower mean of risk adjusted returns for union plans is not the result of outliers in the data. The observed shortfall in performance for union plans could, however, be due to factors correlated with unionism. To further investigate the pattern of underperformance, we turn to the second stage analysis.

Second Stage Results.

Table 3 presents several specifications of the second stage regressions analyzing the determinants of risk adjusted performance $(\alpha){ }^{25}$ With the exception of the union dummy and its interaction with the dummy indicating whether it is a multi-employer plan, all variables are measured as deviations from means so that the intercept represents the mean value of $\alpha$ for the non-union sample holding other plan characteristics equal to the mean for all plans.

${ }^{25}$ The reported t-statistics are based upon robust standard errors corrected for clustering of residuals by pension. 
Specification (1) contains only two dummy variables: one for single-employer union plans, and another for multi-employer union plans. The simple specification suggests that, compared to nonunion plans, single employer union plans under-perform by 2.8 basis points (though the underperformance is not statistically significant at the .1 level) and multi-employer union plans underperform by 46.3 basis points. This simple specification, however, does not adjust for several factors that might influence the administrative expenses of union and non-union plans.

To control for plan differences that might influence performance, we first stratify the sample and estimate separate regressions for DB and DC plans and are shown in specifications (2) and (3). The results indicate that, compared to their nonunion counterparts, single employer union DC plans have higher returns, while single employer union DB plans have lower returns. For both DC and DB plans, union multiemployer plans have diminished performance compared to nonunion plans.

We add controls for other plan characteristics that might affect performance in specifications (4) and (5). The estimated effects of these controls are generally consistent with expectations. For example, the positive effects of per capita assets and the positive but diminishing effects of the number of participants suggest scale economies in both dimensions. The fact that offering another DB or DC plan improves performance suggests economies of scope. Also, the improved performance of older plans could reflect start-up costs and/or improved efficiencies from learning by doing. ${ }^{26}$

Unions can exercise the greatest influence on investments in multi-employer plans and this is where we expect to find the largest union effect. The results in specifications (4) and (5) support this hypothesis. First, we cannot reject the hypothesis that risk-adjusted performance is identical for nonunion and single employer union plans at the .05 level of significance. In contrast, multi-employer

\footnotetext{
${ }^{26}$ These regressions also include year and industry dummies to allow for the fact that risk-adjusted performance might differ systematically across years and the cost of administration could differ across industries because of different work force characteristics.
} 
union plans underperform relative to nonunion plans by 67 basis points among DC plans and by 51 basis points for DB plans. The estimated underperformance is statistically significant at the .01 level.

One possible explanation for the underperformance of the multi-employer plans is that they are more expensive to administer and/or that the employer is less willing to absorb administrative costs into other business operations. To explore this hypothesis, we add administrative and asset management expenses as a percentage of plan assets as a control variable in specfications (6) and (7). Since the first stage regressions are net of expenses, one might expect that the coefficient on administrative expenses would be -1 , but this ignores the fact that many pension plans outsource administration and asset management of their pension in exchange for a reduction in returns. For example, a plan may have a registered investment company manage the plan and "pay" for the administration and asset management through charges to the underlying mutual funds that the registered investment company manages. Such expenses would not appear on the Form 5500, but would be reflected in reduced income on investments. Another reason that the coefficient might be less than one (in absolute value) is that increased expenditures on asset management could improve returns by improving asset selection.

The coefficients on the administrative expense ratio in specifications (6) and (7) imply that a one percentage point increase in the expense ratio reduces risk adjusted performance by 57 basis points in DC plans and 64 basis points in DB plans. Including expenses reduces the estimated negative effects of multi-employer status to 26 basis points for DC plans and 16 basis points in DB plans. Even after controlling for expenses, the underperformance of multi-employer remains statistically significant at the .05 level. 
In the case of single employer plans, we find no evidence that the union plans underperform relative to the non-union plans. In fact, among DC plans, union plans actually enhance performance after adjusting for expenses by 16 basis points.

To test the robustness of the result that the negative effect of unions is greatest in multiemployer plans, we used median regressions to estimate the same second stage models. An advantage of median regression is that the estimates are less sensitive to outliers in the data because the coefficients are chosen to minimize the sum of absolute deviations (as opposed to minimization of squared deviations with OLS). The results, presented in table 4, do not substantively alter our earlier findings. In particular, without controlling for expenses, multi-employer plans (both DB and DC) underperform by about 54 basis points relative to non-union plans. Controlling for expenses reduces the estimated underpeformance of multi-employer plans to 12 to 15 basis points. Overall, we conclude that the effect of unions on the performance of multi-employer plans is largely due to their higher expense charges. We cannot, however, determine whether the higher expense charges are the result of increased costs associated with managing a multi-employer plan, a reduced tendency by the employer to absorb administration costs into other parts of the business, or less efficient operation when the union is given more control over the pension.

Among single employer plans, the union slightly improves the performance of DC pension plans relative to nonunion plans, though there is no statistically significant effect among DB plans. The union could play a positive role as a monitor of activities in DC plans.

The Role of Participant Direction. 
As discussed earlier, the growth of participant direction among DC plans could reduce the ability of the union to target investments that offer lower risk-adjusted returns. To investigate this hypothesis, we estimate the second stage equations for DC plans stratified by participant direction status. The results, presented in table 5, show that the effect of unions on DC plan performance differs depending on whether the plan is participant directed. Whereas multi-employer plans are estimated to underperformn by 37 basis points among trustee-directed DC plans, the effect is only 9 basis points (and statistically insignificant) among participant directed plans. Participant direction appears to eliminate the underperformance of multi-employer DC plans. In the case of single employer plans, unions have no statistically significant effect among the trustee directed plans - but improve performance by 20 basis points among the participant directed plans. It is possible that the union actually helps improve performance among participant directed plans by providing a means by which pension participants can share in the cost of monitoring the selection of funds.

Are the Effects Large Enough to Matter?

While our empirical results suggest that unions can have statistically significant effects on pension performance, the question remains whether the effects are large enough for union members or policy makers to be concerned with. To address this, we consider the implications of the effects of union status on retirement wealth among workers in DC plans.

To provide some sense of the magnitude of the effects, we estimate that between 2000 and 2007, the average union member with a DC plan had annual contributions of \$3,250 (in 2010 dollars). The average real rate of return (net of expenses) on union DC plans over our entire sample period was 
4.5\%. If real contributions for the typical worker are held constant over a 30 year career and a $4.5 \%$ real rate of return is earned, the worker would accumulate real wealth of $\$ 198,273$ by retirement.

Using the above as a benchmark, we estimate the effects of mutli-employer union pensions on retirement wealth. For example, we estimate that multi-employer union plans underperform by 54 basis points relative to nonunion plans (table 4, specification 4). If the underperformance of multiemployer union plans was eliminated, workers could increase pension wealth at retirement by $8.7 \%$ without any increase in annual contributions.

As an alternative illustration, consider the consequences of switching a multi-employer union plan from trustee to participant direction. Our estimates (table 5) suggest that this would improve performance by 28 basis points. Relative to the benchmark situation described above, this would result in 4.6\% more wealth for workers at retirement. Moreover, participant direction gives workers the added advantage of allowing them to adjust their individual portfolios as they age, whereas the trustee-directed plans force all workers in the pension to hold the same portfolio at any given point in time.

Among DC plans, we find that unions improve performance in one case - single employer participant directed plans. Relative to the nonunion counterpart, the union improves performance by 20 basis points (table 5, specification 1 ) and would increase retirement wealth by $3.5 \%$ relative to the benchmark.

\section{Summary and Conclusions}

For decades, unions have attempted to leverage the assets in their pension plans to promote union goals. While ERISA places constraints on what kinds of activities are allowed, it is not simple 
to determine whether a particular activity will harm risk-adjusted performance. Unions could also improve performance by providing a means for workers to share in the cost of monitoring the pension fund manager. Because the union's incentives and ability to sacrifice performance to pursue union goals is altered by plan design, there is no simple answer to the question of "what do unions do to pension peformance?”

Our prediction was that the effect of unions on pension performance could be altered by at least three factors. First, unions will have greater influence in multi-employer plans than single-employer plans because regulatory requirements give unions more control in multi-employer plans. Second, a shift from a DB to a DC plan will shift the cost of underperformance from the employer to the union membership and potentially reduce employer resistance to activism that reduces performance. Finally, a shift from trustee to participant directed DC plans shifts the control over investment decisions from the union leadership to individual members and reduce the odds that investments are directed toward projects that result in reduced performance.

Our empirical results are generally in line with the predictions. For example, our results suggest that multi-employer plans have significant underperformance, but the bulk of the underperformance is the result of higher expenses. Counter to our expectations, we found that the underperformance of multi-employer plans (50 to 70 basis points) is similar for DB and DC plans. For DC plans, we estimate that this underperformance would result in about 9 percent less pension wealth at retirement after a 30 year career. However, eliminating much of this shortfall requires a better understanding of why expenses are so much higher in multi-employer plans.

Among the increasingly popular DC plan, we find that the trustee-directed multi-employer plan where the union exercises the greatest control has the worst performance -- 37 basis points lower than nonunion plans. If the asset allocation decisions are turned over to union members by a switch to 
participant direction, the underperformance is virtually eliminated and we estimate that pension wealth at retirement would increase by almost $5 \%$ for the typical union member over a 30 year career. This suggests that, if given the opportunity, unions may be willing to sacrifice returns to pursue other objectives.

Among single employer DC plans that are participant directed, we find that unions improve performance. One might consider this surprising since the union has no direct control of the pension in single employer plans. However, the union could play a role by providing a means for workers to share in the cost of monitoring the pension administrators and improve the selection of efficient funds.

Our overall conclusion is that unions can have either positive or negative effects on performance. While unions have been slower to switch to participant directed DC plans, if the recent trend continues, we predict that any negative effect of the union on performance will gradually be reduced and that there could be a positive effect on union performance resulting from improved monitoring. 


\section{References}

AFL-CIO. "Exercising Authority, Restoring Accountability: AFL-CIO Proxy Voting Guidelines. 2003. Available at www.aflcio.org .

Agrawal, Ashwini K. “Corporate Governance Objectives of Labor Union Shareholders: Evidence From Proxy Voting.” Working Paper, New York University. September 2008.

and Mandelker, Gershon N. "Large Shareholders and the Monitoring of Managers: The Case

of Antitakeover Amendments.” Journal of Financial and Quantitative Analysis 25 (June 1990): 143161.

Bennett, James, and Johnson, Manuel. "Union Use of Employee Pension Funds: Introduction and Overview.” Journal of Labor Research 2 (Fall 1981): 181-190.

Carhart, Mark M. "On Persistence in Mutual Fund Performance." Journal of Finance 52 (March 1997): 57-82.

Calabrese, Michael. "Building on Past Success: Labor-Friendly Investment Vehicles and the Power of Private Equity.” Working Paper, Center for National Policy. April 1999.

Cohen, Lauren; Frazzini, Andrea; and Malloy, Christopher. "The Small World of Investing: Board Connections and Mutual Fund Returns.” Journal of Political Economy 116 (October 2008): 951-979.

Cremers, Martjin, and Romano, Roberta. "Institutional Investors and Proxy Voting: The Impact of the 2003 Mutual Fund Voting Disclosure Regulation.” Working paper, Yale University. April 2007.

Dorsey, Stuart, and Turner, John. "Union-Nonunion Differences in Pension Fund Investments and Earnings.” Industrial and Labor Relations Review 43 (July 1990): 542-55.

Entine, Jon. “Pension Fund Politics: Do Union “Social Investing” Schemes Benefit Their Workers?” American Enterprise Institute for Public Policy Research, Speeches and Government Testimony, July 2008.

Even, William E., and Macpherson, David A. "Growth of Participant Direction in Defined Contribution Plans,” Industrial Relations 42 (April 2010): 190-208.

Fama, Eugene F., and French, Kenneth R.” Common Risk Factors in the Returns on Stocks and Bonds.” Journal of Financial Economics 33 (February1993): 3-56.

Furchtgott-Roth, Diana. “Pension Plans: How Secure are Union Members’ Investments?” Report for Hudson Institute, Summer 2008. 
Hartsohn, Adrian. Quarterly Pensions Update. New York, NY: Mercer, April 2010.

Hirsch, Barry T. "What Do Unions Do for Economic Performance?” in What Do Unions Do? A Twenty Year Perspective, edited by James T. Bennett and Bruce E. Kaufman, 193-237. New Brunswick, NJ: Transaction Publishers, 2007.

Hustead, Edwin. "Living with Defined Contribution Pensions.” in Living with Defined Contribution Pensions: Remaking Responsibility for Retirement, edited by Olivia Mitchell and Sylvester Schieber, 166-177. Philadelphia, PA: University of Pennsylvania Press, 1998.

Investment Company Institute. "Inside the Structure of Defined Contribution/401(k) Plan Fees: A Study Assessing the Mechanics of What Drives the `All-in’ Fee.” Washington, DC: Investment Company Institute, Spring 2009.

Lee, David, and Mas, Alexandre. "Long-Run Impacts of Unions on Firms: New Evidence from Financial Markets, 1961-1999 .” National Bureau of Economic Research Working Paper Number 14709. Cambridge, MA: National Bureau of Economic Research, February 2009.

McCarthy, David D., and Turner, John A. "Pension Rates of Return in Large and Small Plans." In Trends in Pensions, edited by John A. Turner and Daniel J. Beller, 235-286. Washington, D.C.: U.S. Department of Labor, Pension and Welfare Benefits Administration, 1989.

Mitchell, Olivia S., and Andrews, Emily S. "Scale Economies in Private Multiemployer Pension Plans.” Industrial and Labor Relations Review 34 (July 1981): 286-298.

Morningstar. Ibbotson SBBI 2009 Classic Yearbook: Market Results for 1926-2008. Chicago: Morningstar, Inc., 2009.

Prevost, Andrew K., Rao, Ramesh P. and Williams, Melissa A. "Labor Unions as Shareholder Activists: Champions or Detractors?” February 2009. Available at SSRN: http://ssrn.com/abstract=1119328

Renneboog, Luc, and Szilagyi, Peter G. "The Success and Relevance of Shareholder Activism Through Proxy Proposals.” Working Paper, European Corporate Governance Institute. 2009.

Shleifer, Andrei, and Vishny, Robert W. "Large Shareholders and Corporate Control.” Journal of Political Economy 94 (June 1986): 461-488.

Tonks, Ian. "Performance Persistence of Pension-Fund Managers.” Journal of Business 78 (September 2005): 1917-1942.

Vernuccio, F. Vincent. "Your Retirement or Our Political Agenda.” Competitive Enterprise Institute, Unpublished manuscript, September 2009. 
Table 1. Sample Means for Form 5500 Pension Plan Data.

\begin{tabular}{|c|c|c|c|}
\hline & All & Nonunion & Union \\
\hline Union & $17.9 \%$ & $0 \%$ & $100.0 \%$ \\
\hline Rate of Return (before expenses) & $8.95 \%$ & $8.82 \%$ & $9.53 \%$ \\
\hline Expense Ratio & $0.49 \%$ & $0.40 \%$ & $0.93 \%$ \\
\hline Return Net of Expenses & $8.46 \%$ & $8.42 \%$ & $8.60 \%$ \\
\hline Std. Dev of Net Returns & $9.85 \%$ & $10.09 \%$ & $8.65 \%$ \\
\hline Within plans & $9.58 \%$ & $9.83 \%$ & $8.30 \%$ \\
\hline Between plans & $2.51 \%$ & $2.50 \%$ & $2.57 \%$ \\
\hline Participants & 1,848 & 1,409 & 3,866 \\
\hline Per Capita Assets (\$1000s) & 26.6 & 26.6 & 26.7 \\
\hline Percent Assets Managed Externally & $68.4 \%$ & $70.8 \%$ & $57.4 \%$ \\
\hline Collectively bargained multi-employer plan & $7.8 \%$ & $0 \%$ & $43.2 \%$ \\
\hline Defined Benefit & $31.2 \%$ & $22.9 \%$ & $69.1 \%$ \\
\hline Defined Contribution Plan & $68.8 \%$ & $77.1 \%$ & $30.9 \%$ \\
\hline Participant Directed Defined Contribution Plan & $47.1 \%$ & $54.3 \%$ & $14.1 \%$ \\
\hline 401k Plan & $53.0 \%$ & $61.5 \%$ & $13.8 \%$ \\
\hline Profit Sharing Plan & $58.3 \%$ & $67.6 \%$ & $15.2 \%$ \\
\hline Money Purchase Plan & $5.5 \%$ & $4.2 \%$ & $11.4 \%$ \\
\hline Offer other DB plan & $22.7 \%$ & $19.7 \%$ & $36.9 \%$ \\
\hline Offer other DC plan & $32.8 \%$ & $31.1 \%$ & $41.0 \%$ \\
\hline Number of Plans & 36,012 & 29,833 & 6,179 \\
\hline Number of plan year observations & 488,370 & 401,108 & 87,262 \\
\hline
\end{tabular}


Table 2. Summary Statistics from First Stage Regressions.

Explanation. The numbers presented below represent the average of the estimated FamaFrench coefficients across the pension plans. The dependent variable is excess pension return net of expenses measured in percentage points In parentheses are the percentage of plans for which the corresponding coefficients are statistically different from zero at the .05 level.

$\begin{array}{lccc} & \text { All } & \text { Non-Union } & \text { Union } \\ \text { Alpha } & \text { Plans } & \text { Plans } & \text { Plans } \\ & 0.043 & 0.081 & -0.132 \\ \text { Coefficients on Fama-French Factors } & (97.4 \%) & (97.3 \%) & (97.5 \%) \\ \text { Market - Risk Free } & & & \\ & 0.491 & 0.506 & 0.420 \\ \text { Small - Large Cap } & (98.9 \%) & (99.0 \%) & (98.4 \%) \\ & 0.013 & 0.013 & 0.013 \\ \text { High - Low (Value - Growth) } & (79.2 \%) & (78.9 \%) & (80.9 \%) \\ \text { Term } & 0.016 & 0.012 & 0.031 \\ & (83.7 \%) & (83.4 \%) & (85.0 \%) \\ \text { Default } & -0.059 & -0.081 & 0.041 \\ & (76.9 \%) & (76.7 \%) & (78.1 \%) \\ \text { Average of Regression R-squared } & -0.195 & -0.068 & -0.223 \\ \text { Number of Pension Plans } & (39.8 \%) & (39.8 \%) & (39.8 \%) \\ \text { Number of Observations } & .844 & .849 & .820 \\ & 36,012 & 29,833 & 6,179 \\ & 488,370 & 401,108 & 87,262\end{array}$


Table 3. Second Stage Alpha OLS Regressions.

Explanation. Coefficients are from a regression of the estimated alpha plus the residual from the first stage FamaFrench equations The t-statistics in parentheses are based upon robust standard errors corrected for clustering of residuals by plan.

\begin{tabular}{|c|c|c|c|c|c|c|c|}
\hline & (1) & (2) & (3) & $(4)^{\mathrm{a}}$ & (5) & $(6)^{\mathrm{a}}$ & (7) \\
\hline & All & DC & DB & DC & DB & DC & DB \\
\hline \multirow[t]{2}{*}{ Constant } & 0.0817 & 0.0853 & 0.0716 & 0.0958 & 0.0787 & 0.0771 & 0.00725 \\
\hline & (6.99) & $(6.51)$ & $(2.82)$ & $(7.30)$ & $(2.89)$ & $(5.92)$ & $(0.28)$ \\
\hline \multirow[t]{2}{*}{ Union Single Employer } & -0.0281 & 0.367 & -0.171 & 0.109 & -0.0867 & 0.162 & -0.0248 \\
\hline & $(-0.78)$ & $(6.25)$ & $(-3.55)$ & $(1.80)$ & $(-1.59)$ & $(2.75)$ & $(-0.50)$ \\
\hline \multirow[t]{2}{*}{ Union Multiemployer } & -0.463 & -0.672 & -0.342 & -0.674 & -0.513 & -0.259 & -0.156 \\
\hline & $(-11.6)$ & $(-11.4)$ & $(-6.19)$ & $(-8.92)$ & $(-6.44)$ & $(-3.63)$ & $(-2.06)$ \\
\hline \multirow[t]{2}{*}{ Plan Assets Per Capita/10000 } & & & & 0.00675 & 0.00439 & 0.00568 & 0.00176 \\
\hline & & & & $(3.04)$ & $(0.69)$ & $(3.10)$ & $(0.42)$ \\
\hline \multirow[t]{2}{*}{ Participants in $10,000 \mathrm{~s}$} & & & & 0.361 & 0.106 & 0.325 & 0.0536 \\
\hline & & & & $(8.48)$ & (3.66) & $(7.88)$ & $(1.97)$ \\
\hline \multirow[t]{2}{*}{ Participants in $10,000 \mathrm{~s}^{2}$} & & & & -0.0167 & -0.00143 & -0.0152 & -0.000374 \\
\hline & & & & $(-6.45)$ & $(-1.14)$ & $(-6.24)$ & $(-0.32)$ \\
\hline \multirow[t]{2}{*}{ Plan Age } & & & & 0.0175 & 0.0176 & 0.0166 & 0.0131 \\
\hline & & & & $(14.6)$ & $(11.4)$ & $(14.1)$ & $(9.14)$ \\
\hline \multirow[t]{2}{*}{ Other Defined } & & & & 0.357 & -0.0943 & 0.286 & -0.117 \\
\hline & & & & (11.5) & $(-1.89)$ & $(9.34)$ & $(-2.53)$ \\
\hline \multirow[t]{2}{*}{ Other Defined Contribution } & & & & 0.235 & 0.0525 & 0.199 & -0.0368 \\
\hline & & & & 0.00675 & 0.00439 & 0.00568 & 0.00176 \\
\hline \multirow[t]{2}{*}{ Expense Ratio } & & & & & & -0.571 & -0.641 \\
\hline & & & & & & $(-17.2)$ & $(-15.6)$ \\
\hline Year Dummies Included & No & No & No & Yes & Yes & Yes & Yes \\
\hline Industry Dummies Included & No & No & No & Yes & Yes & Yes & Yes \\
\hline Observations & 488,370 & 336,075 & 152,295 & 336,075 & 152,295 & 336,075 & 152,295 \\
\hline \multicolumn{8}{|l|}{$\begin{array}{l}\text { p-value for equal coefficients on } \\
\text { union single \& union }\end{array}$} \\
\hline multiemployer & 0.000 & 0.000 & 0.007 & 0.000 & 0.000 & 0.000 & 0.121 \\
\hline \multicolumn{8}{|c|}{$\begin{array}{l}\text { p-value for equal coefficients on } \\
\text { union single-employer in DB and }\end{array}$} \\
\hline DC & -- & 0.000 & 0.000 & 0.016 & 0.016 & 0.015 & 0.015 \\
\hline \multicolumn{8}{|c|}{$\begin{array}{l}\text { p-value for equal coefficients on } \\
\text { union multi-employer in DB and }\end{array}$} \\
\hline DC & -- & 0.000 & 0.000 & 0.140 & 0.140 & 0.323 & 0.323 \\
\hline R-squared & 0.00 & 0.00 & 0.00 & 0.09 & 0.05 & 0.10 & 0.08 \\
\hline
\end{tabular}


Table 4. Second Stage Alpha Median Regressions.

Explanation. Coefficients are from a regression of the estimated alpha plus the residual from the first stage FamaFrench equations. T-statistics are in parentheses.

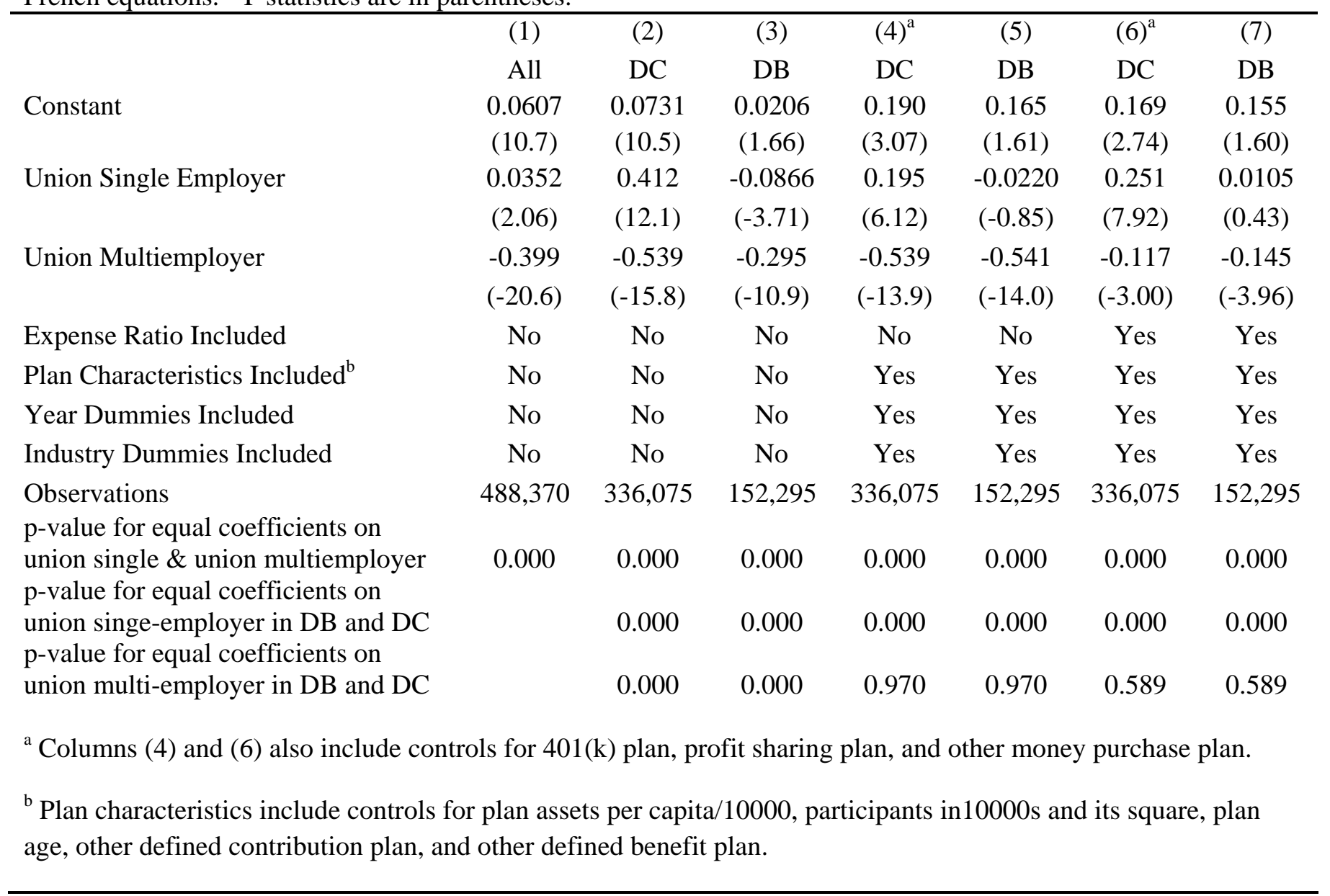


Table 5. Second Stage Alpha Regressions for DC Plans, by Participant Direction Status.

Explanation. Coefficients are from an OLS regression of the estimated alpha plus the residual from the first stage Fama-French equations. T-statistics are in parentheses and are based upon robust standard errors corrected for clustering of residuals by plan.

Participant Directed

Constant

Union Single Employer

Union Multiemployer

Plan Characteristics Included ${ }^{\mathrm{a}}$

Expense Ratio Included

Year Dummies Included

Industry Dummies Included

Sample Size

p-value for equal coefficients on union single \& union multiemployer

p-value for equal coefficients on union singe-employer in participant and trustee-directed plans

$\mathrm{p}$-value for equal coefficients on union multi-employer in participant and trustee-directed plans

R-Squared
0.0632

0.196

$-0.0860$

$(-0.94)$

Yes

Yes

Yes

Yes

229,649

0.011

0.268

0.020

0.12
$-0.00184$

0.0777

$-0.369$

Yes

Yes

Yes

Yes

106,426

0.000

0.268

0.020

0.08

a Plan characteristics include controls for plan assets per capita/10000, participants in10,000s and its square, plan age, other defined contribution plan, other defined benefit plan, 401(k) plan, profit sharing plan, and other money purchase plan. 
Figure 1

Mean Rate of Return by Union Status

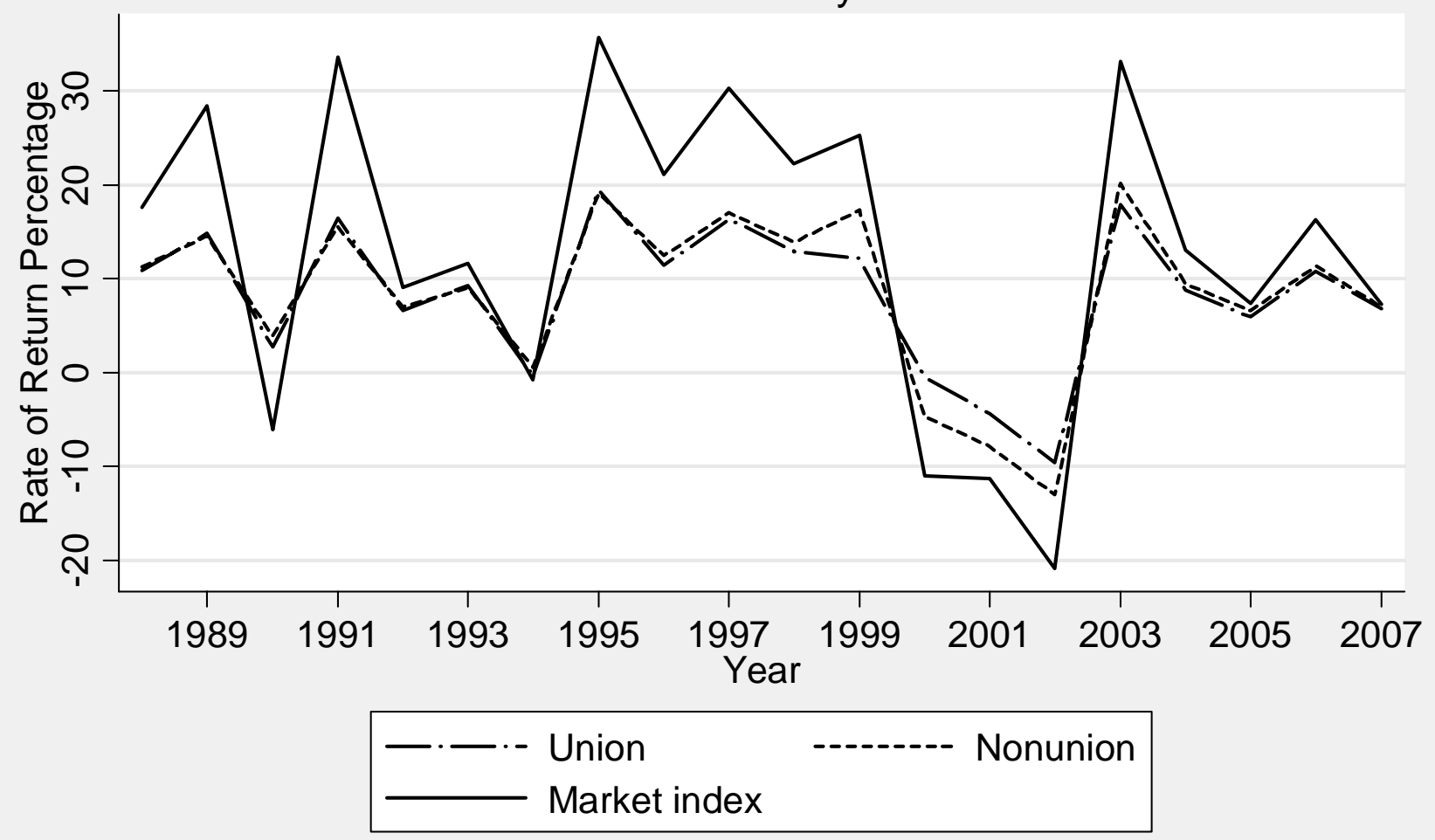

Source : IRS Form 5500 filings with 100 or more participants. 
Figure 2

Alpha Coefficients for Union and Nonunion Plans

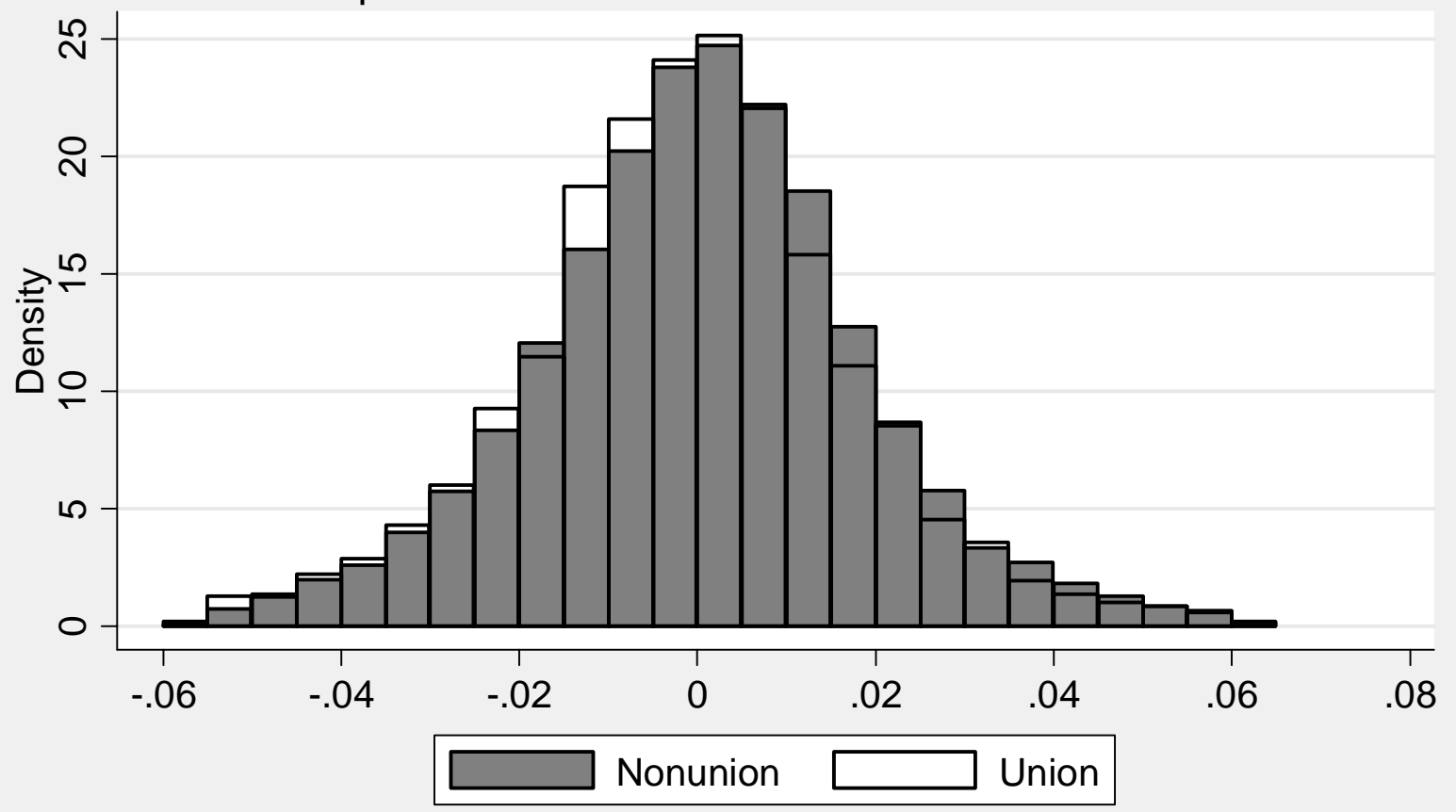

Note: Alpha represents risk-adjusted performance from a five-factor Fama-French model. The sample includes 6,179 union plans and 29,833 nonunion plans. 